Original Research

\title{
Fish Community Dynamics in the Artificial Fishways of Three Different Watersheds, and Fish Passage Evaluations Using a Multi-Metric Fishway Model
}

\author{
Young-Ju Lee', Sang-Jae Lee², Dae-Yul Bae', Kwang-Guk An* \\ ${ }^{1}$ Department of Bioscience and Biotechnology, Chungnam National University, Daejeon 34134, South Korea \\ ${ }^{2}$ Chemical Safety Division, Saemangeum Regional Environmental Office, Jeonju 54872, South Korea
}

Received: 13 April 2018

Accepted: 11 August 2018

\begin{abstract}
We analyzed fish community dynamics in fishways in the Yeongsan, Nakdong, and Geum river watersheds in South Korea and evaluated fish passage efficiency using a multimetric fishway assessment model, along with analyses of water chemistry and flow regime, from April to October 2016. The dominant fish in the fishways was Erythroculter erythropterus, with a mean relative abundance of $28.5 \%$ in all three watersheds. Omnivorous species and tolerant species were the dominant fish guilds in the fishway communities. The highest frequency of fish passage through the fishways occurred during the spawning season from April to June. During the summer monsoon, flow velocity increased rapidly and juvenile and young fish rarely passed through the fishways, which demonstrates that fish passage decreased significantly with increased current velocity $\left(R^{2}=0.463, P<0.05\right)$. The ecological health, based on the fish health model, and the trophic state, based on the nutrient regime, were evaluated in the three watersheds. Overall, the multimetric model of fish passage efficiency, based on structural, hydrological, and biological metrics, showed that the Yeongsan fishway was the most suitable while the other two fishways were unsuitable.
\end{abstract}

Keywords: fishway assessment model, fish guilds, fish community, ecosystem health

\section{Introduction}

In 2010, 16 weirs were constructed on the four major rivers of the South Korean peninsula: the Han, Nakdong (N-R), Geum (G-R), and Yeongsan (Y-R) [1]. The original purpose of the artificial weirs was to

*e-mail:kgan@cnu.ac.kr enhance the use of water resources and to control floods caused by uneven seasonal rainfall distribution in this Asian monsoon region [2]. This region had experienced economic damage from major floods and severe droughts owing to the imbalanced distribution of water resources and problems related to climate change.

Numerous domestic and international studies determined that the construction of these weirs had negative hydrological, physical, chemical, and biological impacts on the bodies of water $[3,4]$. In the four major 
rivers, the most significant impact was a modification of the flow regime from free-flowing river to stagnant lake ecosystem, which resulted in longer water residence time in the weir regions. These flow modifications altered the thermal regime [5], nutrient compositions of nitrogen and phosphorus [6], and levels of dissolved oxygen [7-8]. The increase in area of the lacustrine zone due to increased residence time resulted in changes in the composition of the phytoplankton community from diatoms to blue-green algae, with frequent algal blooms $[9,10]$.

Regional studies in weir regions showed that the non-native species Pectinatella magnifica colonized the stagnant waters that were newly created in the four major rivers and that sediments, which are critical for maintaining physical processes and downstream habitats, were trapped by the weirs [11]. These studies showed that the trapped sediments contained numerous heavy metals and persistent organic pollutants, which indicates chemical pollution of the habitats [12]. Furthermore, construction of the weirs blocked fish migration (e.g., of eels) and separated the spawning habitats of some species from their rearing habitats in the region [13-16]. In addition, composition shifted from running-water fish species to lentic fish. Population sizes of Erythroculter erythropterus and the invasive species Micropterus salmoides increased greatly [17, 18], creating a species imbalance in the ecosystem. Ultimately, the construction of the weirs in the four major rivers resulted in massive fish kills in the G-R, $\mathrm{N}-\mathrm{R}$, and Y-R due to oxygen depletion in the bodies of water.

To counter these multiple ecological impacts, artificial fishways were constructed in the weir regions to connect the upstream and downstream aquatic ecosystems [9, 19]. Some studies have indicated that various fishways constructed without much consideration for ecology and fish movement/migration have become dysfunctional and unnecessary [20]. Their effectiveness has been further diminished by the lack of studies on fish species using the fishways and continued monitoring. For these reasons, fishway monitoring is required for fish passage assessments.

Studies monitoring fishways have primarily been conducted in the United States, Canada, and Australia [21-24]. A representative example is the monitoring of fish using a fishway through visual monitoring and video recording, but a significant limitation of these techniques is that visibility varies greatly depending on the turbidity or transmittance of the water [25]. The mark-recapture method involves capturing fish and marking them by removing part of the fin, then studying the movement of released and recaptured fish [26]. However, fish are highly mobile, which makes this method inefficient, as the probability of recapturing marked individuals is low. Another frequently used monitoring technique is acoustic telemetry, in which an ultrasonic transducer (PIT tag) is attached inside the fish and its movement is tracked by following signals using a hydrophone [27-30]. The disadvantage of this technique is that it is very costly and thus not suitable for large projects that cover a wide-ranging body of water [31-33]. However, the installation of a trap inside a fishway for monitoring purposes enables more precise surveying of fish species and the number of individuals using the fishway at a low cost [25].

Fishways can be categorized as pool, vertical slot, and denil types [34]. The ice harbor fishway is a version of the pool fishway [35]. The structure of an ice harbor fishway consists of overflow and non-overflow sections. The space between the walls is in the form of a pool, which offers a resting space for the fish. The lower area of each overflow section has orifices that facilitate the passage of benthic fish. The installation of ice harbor fishways in Korea was at approximately $8 \%$ in the initial period of construction in 2010, increased to $51.4 \%$ by 2016 , and has continued to increase [36]. Overseas studies on ice harbor fishways have mainly focused on predicting long-distance migration [37]. In Korea, studies have been conducted on hydraulic and hydrological characteristics [20,38] and on monitoring techniques and their applications to multifunctional weir fishways [16, 35, 3941]. However, few comprehensive evaluations or comparative studies on fish passage efficiency have been conducted.

In this study, we investigated fish community structures and movement characteristics upstream and downstream of three weirs in the G-R, Y-R, and N-R watersheds. We analyzed seasonal variation in fish movement, the passage patterns of specific fish species, and fish length distribution in the fishways. In addition, we compared water quality and ecological health assessments based on the index of biological integrity (IBI) conducted upstream of the weirs. We developed a multimetric fishway assessment model based on the approach reported by Choi et al. [41] to evaluate fish passage efficiency in fishways to perform an integrated assessment of the efficiency of ice harbor fishways in Korea.

\section{Material and Methods}

\section{Watershed Sampling and Sampling Sites}

The sampling sites selected were three artificial weirs in the watersheds of the G-R, Y-R, and N-R (Fig. 1). These weirs were built through the government's Four Major Rivers Restoration Project, which began in July 2009 and was completed in April 2012. The G-R watershed, with Gongju Weir $\left(\mathrm{G}_{\mathrm{j}}-\mathrm{w}\right)$, has a total waterway length of $397.79 \mathrm{~km}$ and a basin area of $9,911.83 \mathrm{~km}^{2}$, across which a total of three artificial weirs were constructed through the project. The $\mathrm{G}_{\mathrm{j}}-\mathrm{w}$, which is located in the city of Gongju, Chungcheongnam-do Province, has a height of $7 \mathrm{~m}$ and length of $280 \mathrm{~m}$. It is a movable weir equipped with a lift gate and a bottom-hinged flap gate. The left bank 


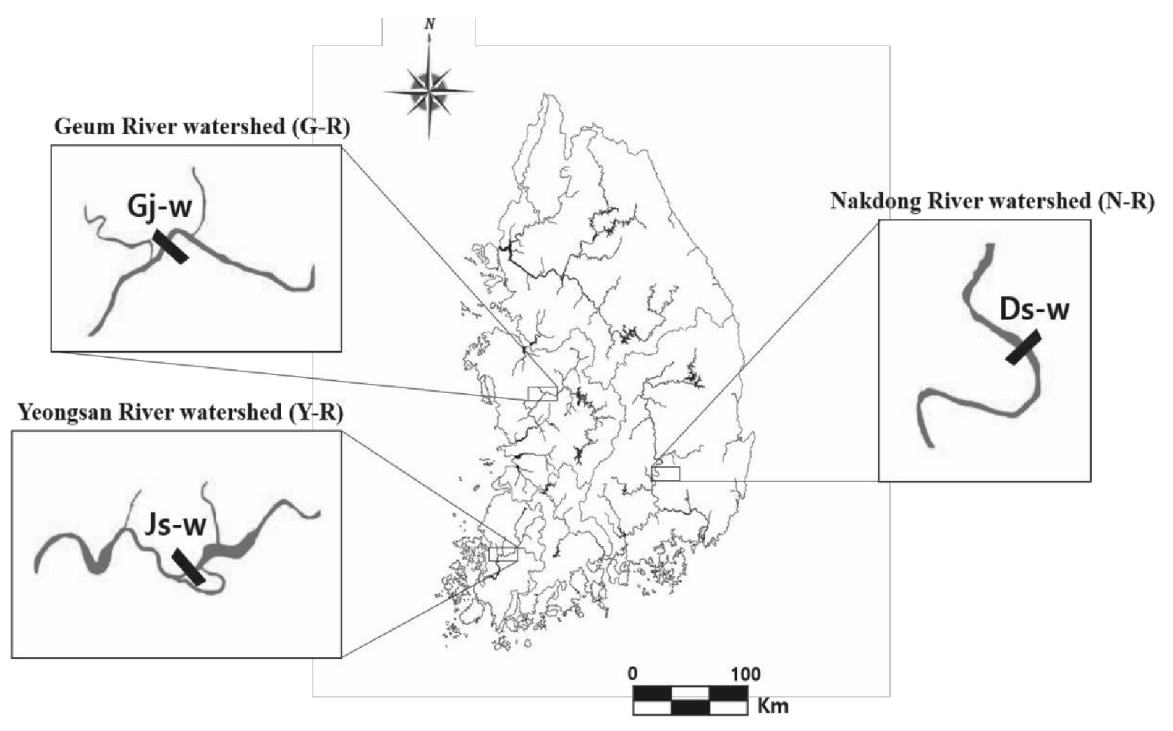

Fig. 1. Monitoring sites and locations of artificial weirs: Gongju Weir $\left(\mathrm{G}_{\mathrm{j}}-\mathrm{w}\right)$ in the Geum River, Juksan Weir $\left(\mathrm{J}_{\mathrm{s}}-\mathrm{w}\right)$ in the Yeongsan River, and Dalseong Weir $\left(\mathrm{D}_{\mathrm{s}}-\mathrm{w}\right)$ in the Nakdong River.

contains a hybrid-type fishway, whereas the right bank contains an ice harbor fishway (6 m wide $\times 140 \mathrm{~m}$ long) directly connected to the artificial weir and a microhydropower plant installed alongside the ice harbor fishway. The watershed of the Y-R, with Juksan Weir $\left(\mathrm{J}_{\mathrm{s}}-\mathrm{w}\right)$, has a total waterway length of $136.0 \mathrm{~km}$ and a basin area of $3,371.4 \mathrm{~km}^{2}$. The $\mathrm{J}_{\mathrm{s}}-\mathrm{w}$, which is located in Naju, has a height of $4.85 \mathrm{~m}$ and a total length of $172 \mathrm{~m}$. It is a movable weir equipped with a shell-type roller gate. Its fishway is not directly connected to the movable weir, and around $250 \mathrm{~m}$ upstream on the right bank there is an ice harbor fishway ( $5 \mathrm{~m}$ wide $\times 104$ $\mathrm{m}$ long) connected to the old river channel, which is structurally designed to allow fish to travel through it. The watershed of the N-R, with Dalseong Weir $\left(D_{s}-w\right)$, has a total waterway length of $521.5 \mathrm{~km}$ and a basin area of $23,717 \mathrm{~km}^{2}$. The $\mathrm{D}_{\mathrm{s}}-\mathrm{w}$ has a total length of $397 \mathrm{~m}$; it is composed of a fixed weir $(277 \mathrm{~m})$ and a movable weir with a rising sector gate $(120 \mathrm{~m})$. The left bank contains a natural-type fishway, whereas the right bank contains an ice harbor fishway ( $7 \mathrm{~m}$ wide $\times 104 \mathrm{~m}$ long), which is directly connected to the movable weir and located toward the center of the river. A micro-hydropower plant is located on the right bank.

\section{Fish Sampling in the Rivers and Fish Trap Monitoring}

Fish were collected in the areas upstream and downstream of the weirs using a casting net $(7 \times 7 \mathrm{~mm})$, a kick net $(5 \times 5 \mathrm{~mm})$, and a fyke net $(5 \times 5 \mathrm{~mm})$, the most popular fish sampling gear in Korea. Monitoring was conducted using the wading method described by the Ministry of Environment/National Institute of Environmental Research [42]. For each sampling site, the sampling distance was set to $200 \mathrm{~m}$. The duration of sampling with the casting net and kick net was limited to $50 \mathrm{~min}$ for the catch per unit effort (CPUE); the fyke net was set and checked after $24 \mathrm{~h}$. The stream order was determined using a 1:120,000-scale map based on the method described by Strahler [43], and the collected fish were identified onsite based on Kim and Park [44]. Species that could not be easily identified were fixed in a $10 \%$ formaldehyde solution, transported to the laboratory, and identified. Fish less than $20 \mathrm{~mm}$ in total length were excluded from the count.

Monitoring for each fishway was conducted by installing a trap in the fishway and directly collecting fish onsite. The traps used for the inspection were assembled from stainless steel frames of $1.0 \mathrm{~m}$ (width) $\times 1.0 \mathrm{~m}$ (length) $\times 1.0 \mathrm{~m}$ (height), whereas the trap used in the Y-R fishway was $0.8 \times 1.5 \times 1.0 \mathrm{~m}$, in line with the size of the fishway. The nets inside the trap were constructed of $4 \times 4 \mathrm{~mm}$ mesh to collect fish regardless of size. In addition to collecting fish swimming from downstream to upstream of the weir through the fishway, the entrance of the trap was designed to be unidirectional in shape. A total of five traps were installed in fishways of the G-R watershed, three in fishways of the Y-R watershed, and four in fishways of the N-R watershed; all were set and monitored over $24 \mathrm{~h}$. The sampling period was from April to October 2016, during which a total of five investigations were conducted to monitor whether the type of fish passing from downstream to upstream through the fishways differed by sampling period. Furthermore, to determine whether the location of the trap affected the number of fish caught, the fish collected from each trap were recorded separately, and the total length and weight of each fish was measured. In addition, a flow meter (Flowatch, JDC Electronics, Yverdon-les-Bains, Switzerland) was used to measure the water velocity at each trapping site within the fishways. 


\section{Chemical Analysis}

To investigate the relationship between fish communities and water quality, we obtained water quality data for the months in which monitoring was conducted at each site using the Ministry of Environment Water Information System (http://water. nier.go.kr). The water quality variables analyzed in this study were total nitrogen (TN), total phosphorus (TP), biological oxygen demand (BOD), suspended solids (SS), and chlorophyll-a (CHL-a).

\section{Fish Guild Analysis and Multi-Metric Biological Health Assessments}

The fish collected at each sampling site were categorized by tolerance guild as follows: sensitive species (SS), which disappear rapidly because of water pollution or disturbance; tolerant species (TS), which possess some degree of tolerance; or intermediate species (IS), whose tolerance level is between those of the other two species. The fish were also categorized by trophic guild: omnivores $(\mathrm{O})$, insectivores $(\mathrm{I})$, carnivores $(\mathrm{C})$, and herbivores $(\mathrm{H})$ [45]. We evaluated biological health using a multimetric fish health assessment model based on the IBI. We used a version of the IBI model that was originally developed by Karr [46] and revised by An et al. [47] in accordance with the ecological habitat in Korea, then established as the model for the assessment of ecosystem health [42]. This multimetric assessment model used a total of eight metrics, with each metric given a value of 1,3 , or 5 and the scores summed at the end. The grading system in the model was based on the standards set by the Ohio Environmental Protection Agency (EPA) [48] and the U.S. EPA [49], with A (excellent condition) ranging from 36 to $40, \mathrm{~B}$ (good) from 26 to 35, C (fair) from 16 to 25 , and D (poor) less than 15. The assessment model for the efficiency of ice harbor fishways was developed by Choi et al. [41], and we used these criteria to assess the fishways. This assessment model was based on nine metrics, including structural metrics, hydrological metrics, and biological

Table 1. Fish species composition in the fishways of the Geum River (G-R), Yeongsan River (Y-R), and Nakdong River (N-R) watersheds; only fish species with $>1.0 \%$ relative abundance are shown.

\begin{tabular}{|c|c|c|c|c|c|c|c|c|c|c|c|c|c|}
\hline \multirow{2}{*}{ Species } & \multirow{2}{*}{$\mathrm{T}_{\mathrm{o}}$} & \multirow{2}{*}{$\mathrm{T}_{\mathrm{r}}$} & \multicolumn{3}{|c|}{ G-R Watershed } & \multicolumn{3}{|c|}{ Y-R Watershed } & \multicolumn{3}{|c|}{ N-R Watershed } & \multirow{2}{*}{ TNI } & \multirow{2}{*}{$\begin{array}{l}\text { RA } \\
(\%)\end{array}$} \\
\hline & & & $\mathrm{GR}_{\mathrm{u}}$ & $\mathrm{GR}_{\mathrm{d}}$ & $\mathrm{GR}_{\mathrm{F}}$ & $\mathrm{YR}_{\mathrm{u}}$ & $\mathrm{YR}_{\mathrm{d}}$ & $\mathrm{YR}_{\mathrm{F}}$ & $\mathrm{YR}_{\mathrm{u}}$ & $\mathrm{YR}_{\mathrm{d}}$ & $\mathrm{YR}_{\mathrm{F}}$ & & \\
\hline Erythroculter erythropterus & TS & $\mathrm{C}$ & 315 & 62 & 92 & & & & 153 & 303 & 1016 & 1,941 & 28.5 \\
\hline Lepomis macrochirus $\dagger$ & TS & I & 73 & & & 332 & 211 & 88 & 29 & 12 & 1 & 746 & 10.9 \\
\hline Squalidus japonicus coreanus & TS & $\mathrm{O}$ & 181 & 192 & 280 & & 1 & & & & & 654 & 9.6 \\
\hline Hemibarbus labeo & TS & I & 171 & 73 & 194 & 19 & 5 & 109 & 6 & 4 & 52 & 633 & 9.3 \\
\hline Coilia nasus & IS & $\mathrm{C}$ & & & & & 494 & & & & & 494 & 7.2 \\
\hline Micropterus salmoides $\dagger$ & TS & $\mathrm{C}$ & 50 & 52 & & 87 & 91 & 1 & 41 & 45 & 1 & 368 & 5.4 \\
\hline Squalidus chankaensis tsuchigae & IS & $\mathrm{O}$ & & & & 25 & 22 & 176 & 35 & 27 & & 285 & 4.2 \\
\hline Opsariichthys uncirostris amurensis & TS & $\mathrm{C}$ & 22 & 76 & 85 & 33 & 10 & & 37 & 6 & 11 & 280 & 4.1 \\
\hline Microphysogobio jeoni & IS & I & 7 & 15 & 148 & & & & & & & 170 & 2.5 \\
\hline Acanthorhodeus macropterus & IS & $\mathrm{O}$ & 14 & 84 & & 44 & 19 & & & & & 161 & 2.4 \\
\hline Zacco platypus & TS & $\mathrm{O}$ & 29 & 101 & 4 & & & 2 & 1 & & & 137 & 2.0 \\
\hline Pseudogobio esocinus & IS & I & 31 & 59 & & & 3 & 28 & 5 & 9 & & 135 & 2.0 \\
\hline Hemiculter eigenmanni & TS & $\mathrm{O}$ & 18 & 62 & & 25 & 12 & 3 & 7 & 1 & & 128 & 1.9 \\
\hline Acheilognathus lanceolatus & IS & $\mathrm{O}$ & 16 & 98 & & & & & & & & 114 & 1.7 \\
\hline Carassius auratus & TS & $\mathrm{O}$ & 70 & 12 & & 18 & 3 & & 4 & 2 & & 109 & 1.6 \\
\hline Rhinogobius brunneus & IS & I & 8 & 48 & 2 & 21 & & & 11 & 7 & 1 & 98 & 1.4 \\
\hline Squaliobarbus curriculus & IS & $\mathrm{O}$ & 40 & 36 & 17 & & & & & & & 93 & 1.4 \\
\hline Channa argus & TS & $\mathrm{C}$ & & & & 86 & & & 1 & & & 87 & 1.3 \\
\hline \multicolumn{3}{|l|}{ Total Number of Species } & 26 & 30 & 12 & 15 & 17 & 9 & 16 & 11 & 6 & 42 & \\
\hline \multicolumn{3}{|l|}{ Total Number of Individuals } & 1,102 & 1,036 & 827 & 702 & 895 & 416 & 335 & 420 & 1,082 & 6,815 & \\
\hline
\end{tabular}

$\dagger$ : Exotic species, $\uparrow$ : Endangered species, $\mathrm{T}_{\mathrm{o}}$ : Tolerance guilds, $\mathrm{T}_{\mathrm{r}}$ : Trophic guilds, RA: Relative abundance, TS: tolerant species, IS: intermediate species, SS: sensitive species, O: omnivores, I: insectivores, C: carnivores, TNI: total number of individuals, RA: relative abundance 
metrics in relation to fish passage through the fishways. Each metric was scored from 1 to 4 points, and the total score was calculated as the sum of all individual metric scores. Total scores of 31-36 were assessed as excellent, 24-30 as good, 17-23 as poor, and 9-16 as very poor.

\section{Statistical Analysis}

To analyze the spatial and seasonal differences in fish passage through the fishways, we conducted one-way analysis of variance (ANOVA) using SPSS v. 22.0 KO for Windows (IBM, Armonk, NY, USA). We conducted regression analyses and correlation analyses using SigmaPlot v. 10.0 (Systat Software, San Jose, CA, USA).

\section{Results and Discussion}

\section{Fish Fauna and Compositions}

A total of 42 species and 6,815 individuals were collected in the three different watersheds (Table 1). The most dominant fish species were E. erythropterus (28.5\%) and Lepomis macrochirus (10.9\%), followed by Squalidus japonicus coreanus (9.6\%), Hemibarbus labeo (9.3\%), Coilia nasus (7.2\%), and M. salmoides (5.4\%). The movement of dominant E. erythropterus along fishways from downstream to upstream of the weir typically results in a critical imbalance in fish communities because E. erythropterus is a carnivore that feeds on domestic species, a problem that requires a solution. E. erythropterus dominated the community by $15.5 \%$ in the G-R fishway, whereas its abundance was low in the Y-R fishway. The presence of L. macrochirus (bluegill), the subdominant species, was confirmed upstream of weirs in the G-R watershed. In the Y-R and N-R watersheds, this species was present upstream, downstream, and in the fishways. The dominance rate in the Y-R was particularly high (31.3\%). Three exotic fish species were collected - Lepomis macrochirus, Micropterus salmoides, and Carassius cuvieri, and their overall relative abundance was $16.3 \%$. L. macrochirus, which is a top carnivore that exerts high predation pressure, made up the highest proportion (66.8\%) among the three exotic species. Exotic species distribution in the stream ecosystem cannot be directly explained by water chemistry only, but other environmental factors should be considered.

\section{Trophic Guilds and Tolerance Guild Analysis}

Trophic guilds were assessed in the regions upstream and downstream of the weirs (Fig. 3). The proportion of omnivores was highest in the G-R watershed, and the proportion of insectivores was highest in the Y-R watershed $(38.1 \%)$. This appeared to be due to the dominance of L. macrochirus, which was approximately $10 \%$ near the N-R watershed. The proportion of
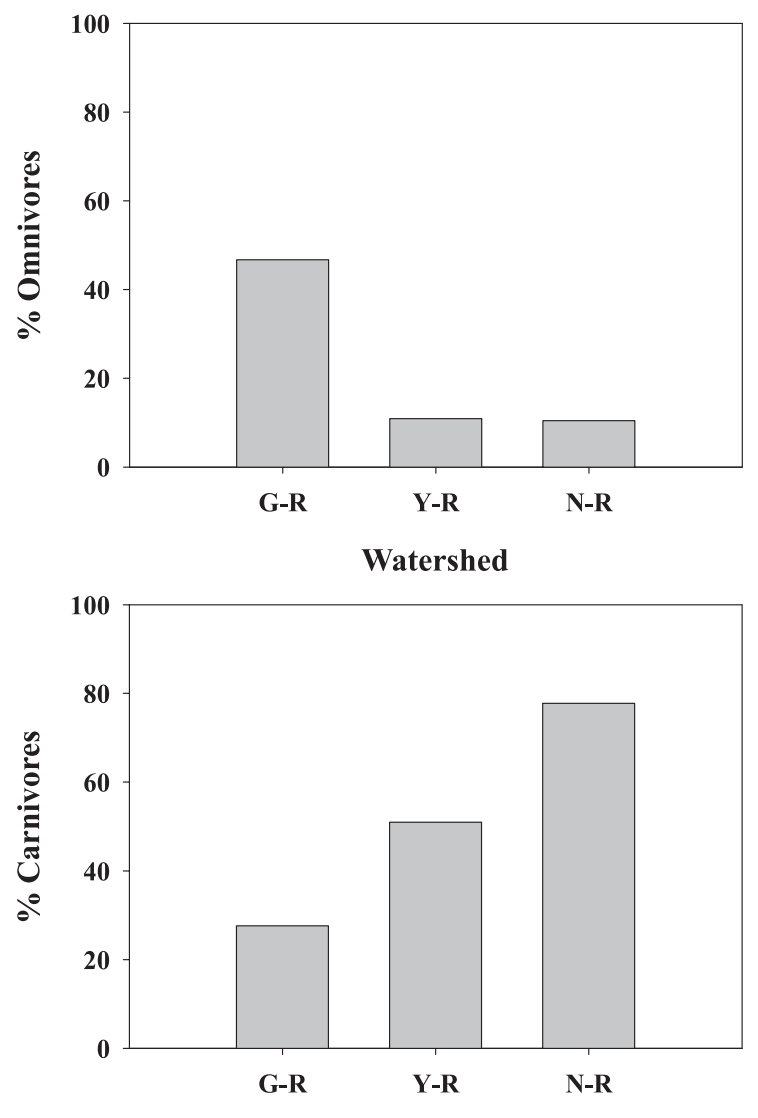

Watershed
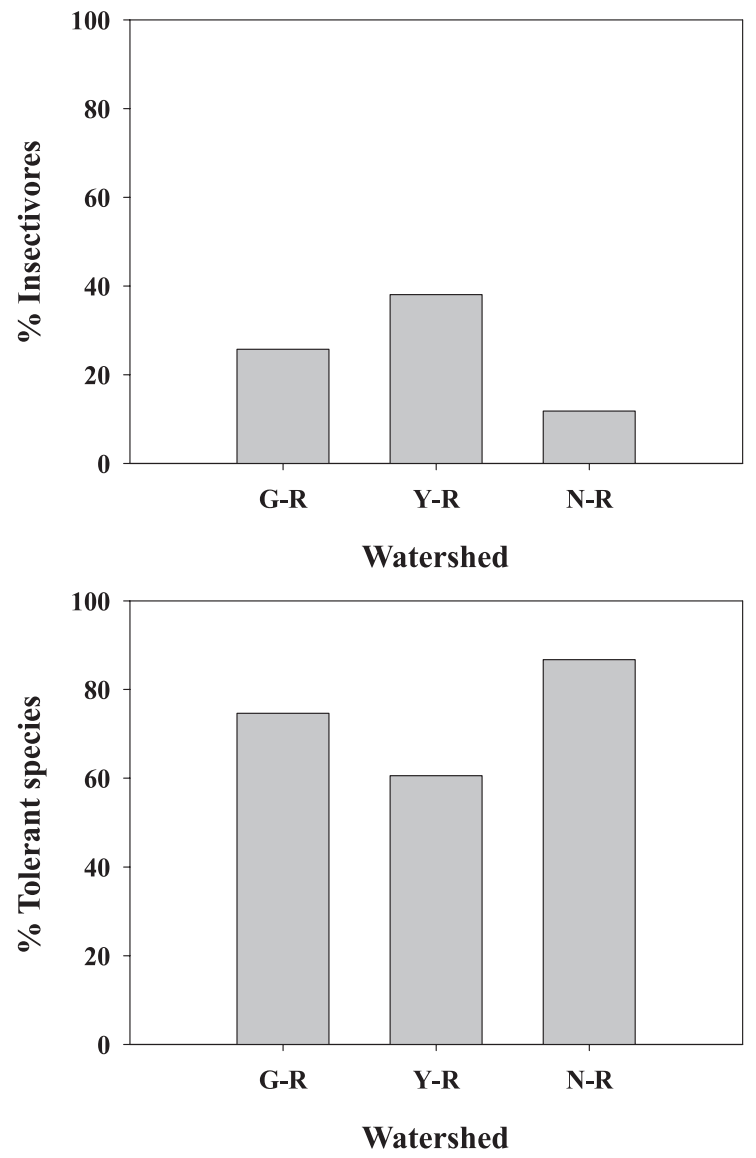

Fig. 2. Fish tolerance and trophic guilds upstream and downstream of weirs. 
carnivores was $77.8 \%$ in the N-R watershed because of the dominance of E. erythropterus, which indicates that different characteristics of the watersheds were due to the trophic characteristics of the dominant species. The analysis of fish tolerance guilds in the upstream and downstream regions revealed that tolerant species constituted $>60 \%$, which indicates ecological degradation. The proportion of tolerant species was particularly high, approximately $90 \%$, in the N-R watershed, and lowest, approximately $60 \%$, in the Y-R. The number of individuals and species in tolerant species increased with degradations of chemical water quality. Such condition made tolerant species dominant in the H-R. The dominance of tolerant species and the rarity of sensitive species were mainly due to nutrient enrichment and organic matter loading from wastewater disposal plants and agricultural regions.
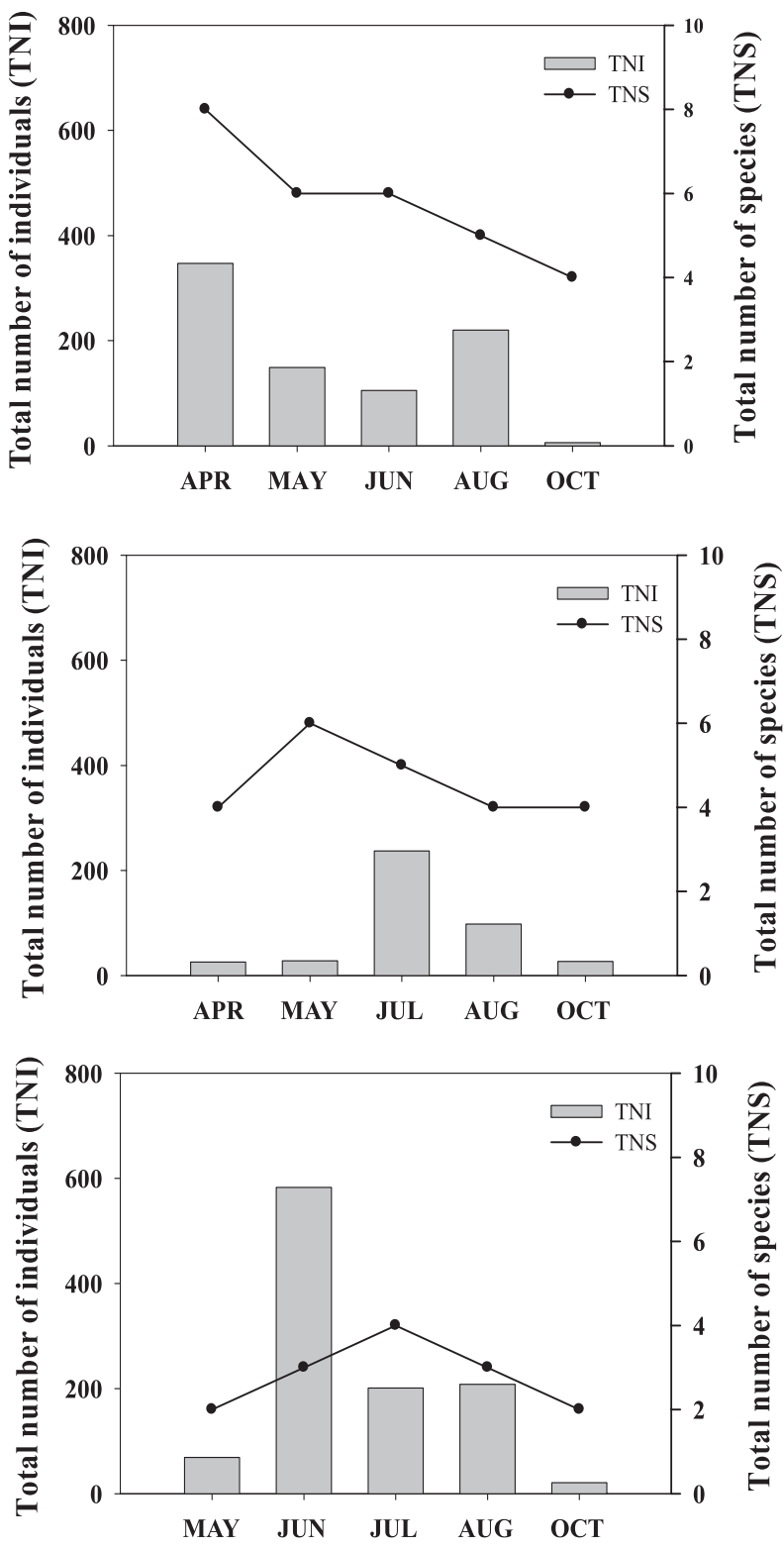

Fig. 3. Seasonal variation of fish passage, based on fish trap monitoring, in the fishways.

\section{Seasonal Variation of the Fish Composition in the Fishways}

Based on the periodic characteristics of fish collected from traps in the G-R watershed fishway (Fig. 3), a maximum of eight species (first survey) and a minimum of four species (fifth survey) were observed, with an average of six species throughout the research period. According to analyses of the number of fish species and population size, a maximum of 347 individuals (first survey) and a minimum of six individuals (fifth survey) were collected, with an average of 165 individuals throughout the research period, with a general decreasing trend in the number of species and population size. The number of species (four) and individuals (six) collected in the fifth sampling period (October) was particularly low. This appeared to have been caused by rapidly decreasing water temperatures and the consequently slower metabolism and swimming ability of the fish. In the N-R watershed fishways, a maximum of four species (third survey) and a minimum of two species (first and fifth surveys) were collected, with an average of three species appearing throughout the research period. Regarding the overall size of the fish population, a maximum of 585 individuals (second survey) and a minimum of 21 individuals (fifth survey) were collected, with an average of 216 individuals throughout the research period. E. erythropterus in particular had a relative abundance of $95.7 \%$ and $97.1 \%$, respectively, in the first and second surveys. They appeared to constitute the majority of the ascending fish population owing to their spawning season. Conversely, the proportion of E. erythropterus was $78-90 \%$ throughout the third to fifth study periods; this was attributed to their large size and superior swimming ability relative to other species.

During the monsoon season from July to August, no exotic fish were found in the G-R watershed, although they were found in the Y-R and N-R watersheds (Fig. 4). Their proportion in the Y-R fishways was approximately $20 \%$ in the premonsoon period, increased by $60 \%$ during the monsoon, and then fell to $<30 \%$ in the postmonsoon period. This indicates that the exotic fish passed through the weirs during periods of high flow, further extending their distribution. The exotic fish were observed only during the monsoon in the N-R fishways. The proportion of the dominant species in the G-R fishways, S. coreanus, was $80 \%$ before the monsoon; however, during the monsoon, this declined to $10 \%$, and this species was nonexistent after the monsoon. In the Y-R fishways, L. macrochirus, the dominant species, constituted only $10 \%$ prior to the monsoon period, increased to approximately $60 \%$ during the monsoon, and dropped off to $30 \%$ after the rainfall. In the N-R fishways, there were no rainfall-related changes in the proportion of the dominant species, E. erythropterus, which remained consistent at approximately $95 \%$. With increased flow rates upstream and downstream of the weirs and fishways owing to rainfall, the smaller $S$. coreanus were unable to use the fishways, as they 

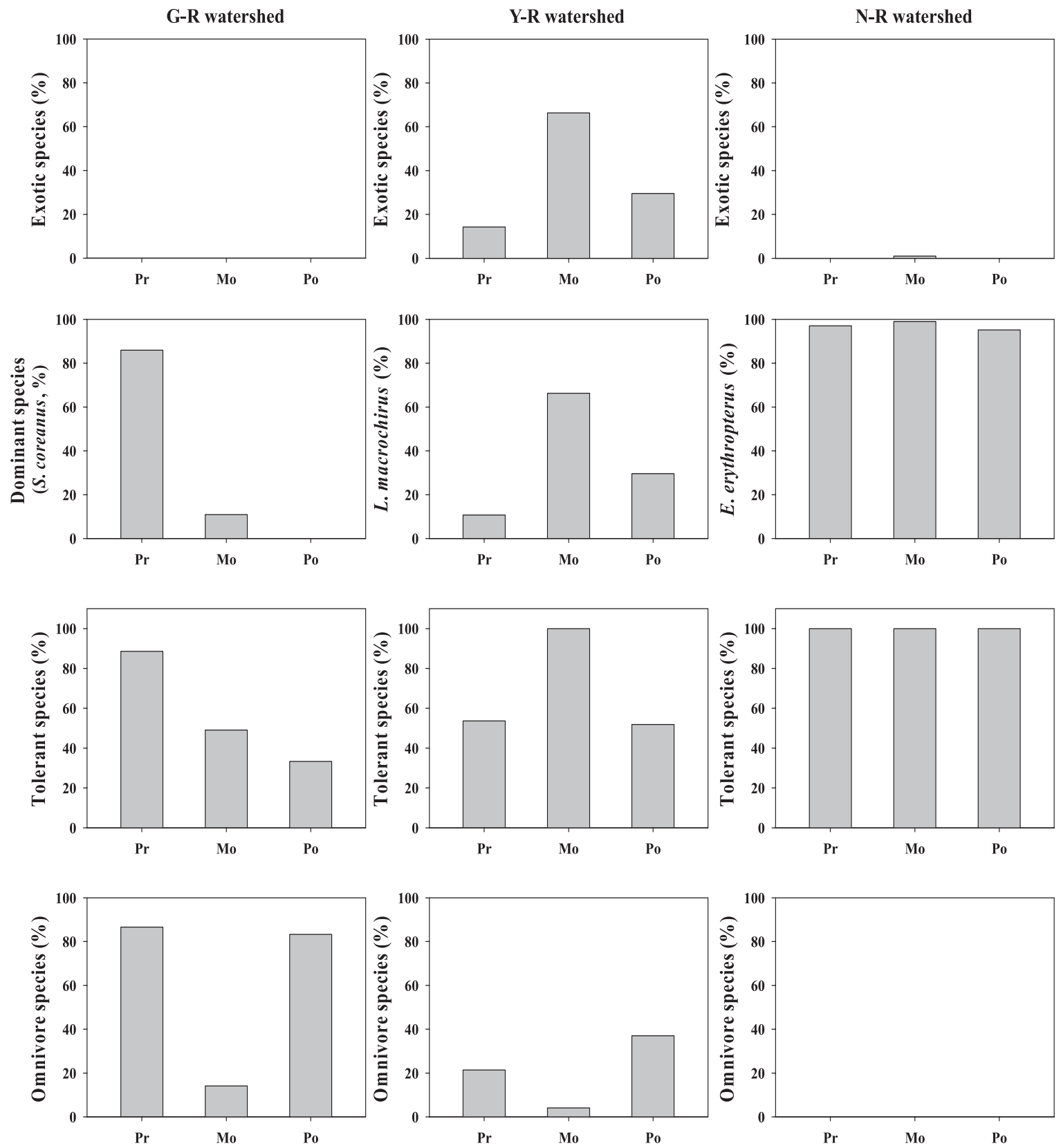

Fig. 4. Seasonal fish composition and guild analysis in the fishways (Pr: premonsoon, Mo: monsoon, Po: postmonsoon).

could not pass through them. Conversely, the flow rate increase did not impact E. erythropterus, a large species, which demonstrates that the results varied based on fish size. Changes in the proportion of omnivores following the monsoon season indicated a trend toward fewer omnivores compared to other regions of the G-R and Y-R watersheds, and the rate of change in the fishways of the G-R watershed region was higher than that in the Y-R watershed. In the N-R watershed, no omnivorous fish species were collected.

\section{The Relationship between Fish Passage and Water Velocity}

The analysis of fish passage in the trap monitoring of the G-R fishway (Fig. 5) showed that 7 species and
314 individuals were collected in Trap 1 (Tr-1), 8 species and 78 individuals were collected in $\operatorname{Tr}-2$, and 8 species and 129 individuals were collected in $\mathrm{Tr}-3$. The highest number of individuals (827) was collected in Tr-5. The proportions of $\operatorname{Tr}-1$ and $\operatorname{Tr}-5$ were $38 \%$ and $20 \%$, respectively, which indicates that fish preferred the edges of the fishways. Flow regime analysis in the fishways showed that the velocity averaged $1.0 \pm 0.31 \mathrm{~m} / \mathrm{s}$ at $\mathrm{Tr}-1$, $1.1 \pm 0.16 \mathrm{~m} / \mathrm{s}$ at $\operatorname{Tr}-2,1.12 \pm 0.29 \mathrm{~m} / \mathrm{s}$ at $\operatorname{Tr}-3,1.18 \pm 0.08 \mathrm{~m} / \mathrm{s}$ at $\mathrm{Tr}-4$, and $0.92 \pm 0.13 \mathrm{~m} / \mathrm{s}$ at $\mathrm{Tr}-5$. These results indicate substantial differences in the current velocity depending on the location of the trap within the fishway. Moreover, the flow speed was the slowest at Tr-1 and Tr-5, where the greatest number of fish were collected, which indicates that many fish moved through opposite ends of the fishways where the flow velocity was slower. 

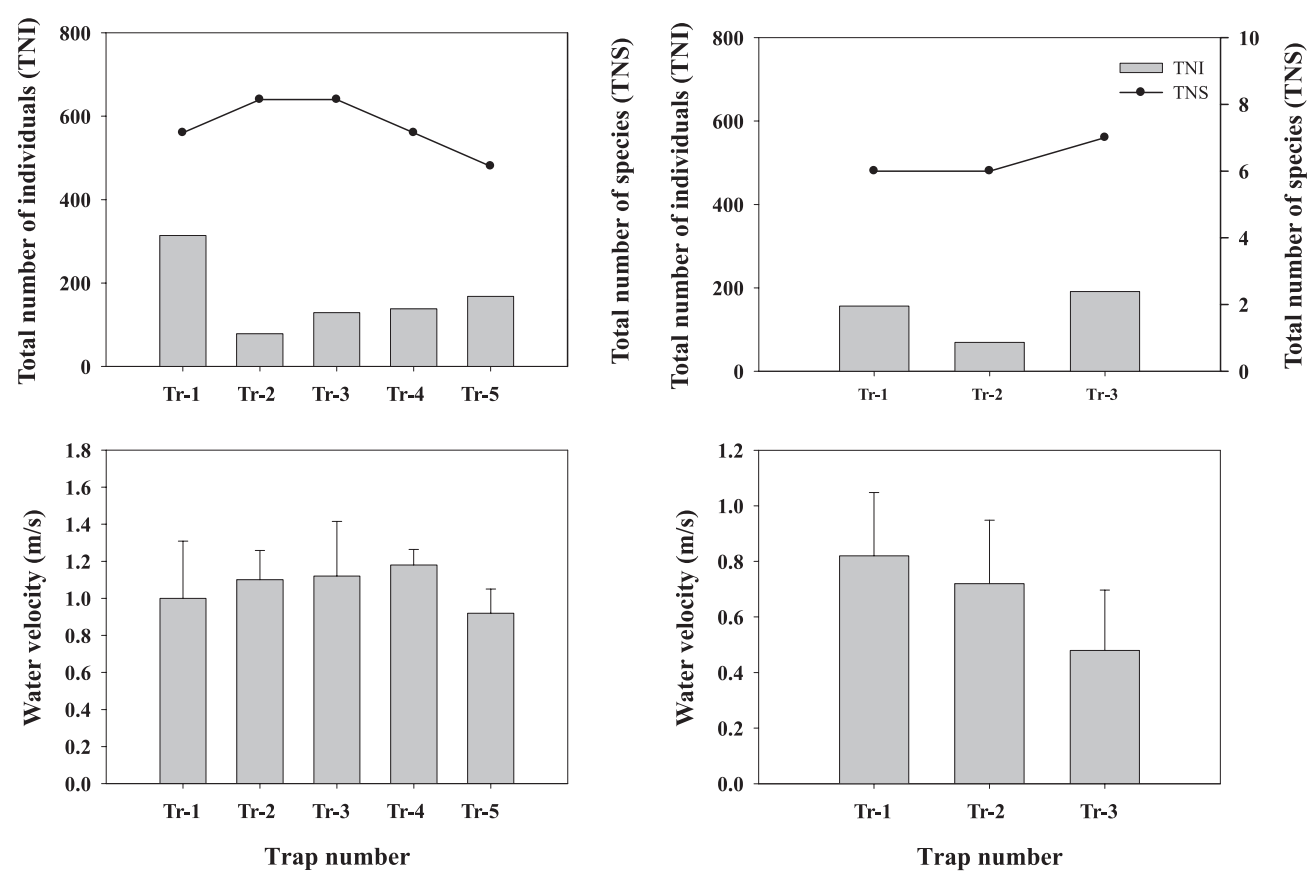

Fig. 5. Total number of individual fish and fish species in relation to the positions of traps in the fishways; data from the N-R watershed were not available.

In the Y-R fishway, Tr-1 had 6 species and 156 individuals, Tr-2 had 6 species and 69 individuals, and Tr-3 had 7 species and 191 individuals. The proportion of fish was $37.5 \%$ in $\mathrm{Tr}-1$ and $46 \%$ in $\mathrm{Tr}-3$. This indicates that most fish moved through the fishways at opposite sides, similar to the pattern observed in the weir in the G-R watershed. The current velocity averaged $0.82 \pm 0.23 \mathrm{~m} / \mathrm{s}$ in $\operatorname{Tr}-1,0.72 \pm 0.23 \mathrm{~m} / \mathrm{s}$ in $\operatorname{Tr}-2$, and $0.48 \pm 0.22 \mathrm{~m} / \mathrm{s}$ in $\mathrm{Tr}-3$, similar to previous research by Park and An [40].

\section{Stream Health Assessments in the Weirs and the Relationship between Fish Guilds and Water Chemistry}

Ecological health, based on fish multi-metric model, was evaluated in the upstream of three weirs (Table 2). The health model value averaged 17.6 in G-R fishway, indicating a fair condition (' $\mathrm{C}$ '), while the values in Y-R and N-R fishways were 14.8 and 15.2, respectively, with ' $\mathrm{D}$ ' and poor condition. Based on changes to total metric values throughout the study period, the values for G-R were highest in the 1 st study (April) and the $4^{\text {th }}$ study (August) with a metric value of 20. It was lowest with 14 in the $3^{\text {rd }}$ study (June), indicating that health declined with rising water levels and flow volume. The model value was highest (18) on July in the Y-R; however, it was 14 in all other studies, or at the "poor condition." In particular, during the rainy season ( $3^{\text {rd }}$ study), the rise in relative abundance of L. macrochirus, both the dominant species and insectivores, led to higher values in M5 (native omnivore ratio), for M1 (total number of native fish species), resulting in a total of
10 species, causing differences with other study periods. Upstream of weirs in the N-R, the M5 score was the highest possible for the metric during the $3^{\text {rd }}$ to $5^{\text {th }}$ study periods. The dominance of carnivores and extremely low proportions of omnivores indicated changes to metric values throughout the study period. All three upstream regions resulted in values of ' 1 ', lowest metric, for M2 (number of riffle benthic species), M3 (number of sensitive species), and M4 (percentage of individuals as tolerant species). For M8, which illustrates the portion of individuals with abnormalities, no such individuals were collected and thus the value given was the highest possible score, '5.' In the case of metrics with the lowest values possible, the construction of the weir led to longer periods of water remaining upstream, increasing sedimentary deposits and creating a fish community structure in which it was impossible for riffle benthic species to survive; as such, this appears to have led to the phenomenon of dominance by tolerant species, omnivores, and carnivores.

Based on fish tolerance guilds and water quality parameters, the proportion of TS collected upstream in watersheds (Fig. 7) per study period was generally very high, averaging more than $70 \%$. The proportion of SS was less than $3 \%$, a significant difference between the proportions. By location, in the G-R watershed, the proportions of SS and TS were highest in the June study period; in the Y-R watershed, SS appeared throughout all study periods, but their proportion was less than $1 \%$. In the N-R watershed, no SS were collected.

In the analysis of water quality, the average concentrations of TN and TP were higher than $1.5 \mathrm{mg} / \mathrm{L}$ and $35 \mu \mathrm{g} / \mathrm{L}$, respectively. According to the standards 


\begin{tabular}{|c|c|c|c|c|c|c|c|c|c|c|}
\hline \multirow{5}{*}{ 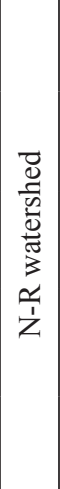 } & in & $-\widehat{0}$ & $\stackrel{e}{e}$ & $\stackrel{e}{e}$ & $-\underset{\varrho}{\varrho}$ & $n \stackrel{0}{0}$ & $-\hat{\mathfrak{e}}$ & $-E$ & $\underbrace{e}_{n}$ & $\div 0$ \\
\hline & $\exists$ & $-\infty$ & $\underset{-}{(2}$ & $\stackrel{e}{e}$ & $-\widetilde{\tilde{m}}$ & $n \underset{v}{\stackrel{f}{a}}$ & $-\stackrel{\tilde{m}}{\ddot{g}}$ & $-\underset{f}{\stackrel{f}{f}}$ & $\underset{n}{e}$ & $\div 0$ \\
\hline & 鬲 & $-\subsetneq$ & $\stackrel{e}{e}$ & $\stackrel{e}{e}$ & $\begin{array}{r}\tilde{n} \\
-\infty \\
\infty\end{array}$ & $n \stackrel{\overparen{?}}{=}$ & $-\frac{\hat{\theta}}{\dot{e}}$ & - 底 & $\underset{n}{e}$ & $\div 0$ \\
\hline & 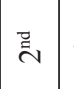 & $-E$ & $\stackrel{e}{e}$ & $\stackrel{e}{e}$ & $-\underset{\overparen{f}}{\stackrel{\overparen{E}}{E}}$ & m $\frac{\widehat{\sigma}}{2}$ & $-\stackrel{\overparen{\vartheta}}{\rightleftarrows}$ & $-\widehat{\vec{c}}$ & $\underset{n}{\hat{e}}$ & $\pm \widehat{\ominus}$ \\
\hline & $\stackrel{ \pm}{-}$ & $-\infty$ & $\underset{\mathfrak{e}}{\mathfrak{e}}$ & $\underset{\mathfrak{e}}{\mathfrak{e}}$ & $-\frac{6}{8}$ & $m \stackrel{\widehat{F}}{\underset{d}{d}}$ & $-\frac{\tilde{n}}{\tilde{c}}$ & $-\stackrel{6}{=}$ & $\underset{n}{\hat{e}}$ & $\pm \widehat{\ominus}$ \\
\hline \multirow{5}{*}{ 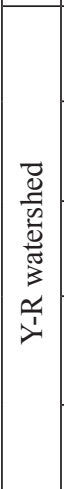 } & 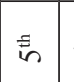 & $-E$ & $\underset{-}{0}$ & $\underset{-}{0}$ & $-\frac{\hat{g}}{i}$ & $m \stackrel{\frac{1}{m}}{\frac{1}{n}}$ & $-\underset{f}{\stackrel{f}{c}}$ & $-\widehat{\text { I }}$ & êc & $\pm \widehat{\ominus}$ \\
\hline & F & $-\widehat{\infty}$ & $\stackrel{e}{e}$ & $\stackrel{e}{e}$ & $-\frac{\tilde{n}}{\infty}$ & m $\frac{\overparen{n}}{\tilde{c}}$ & $-\frac{\widehat{\vartheta}}{\hat{\theta}}$ & $-\widehat{\vec{\sigma}}$ & @e & $\pm \widehat{\ominus}$ \\
\hline & $\stackrel{m}{m}$ & $n \stackrel{\ominus}{\ominus}$ & $\stackrel{\Omega}{\simeq}$ & 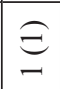 & $-\frac{\tilde{m}}{\infty}$ & i $\overparen{\overbrace{}}$ & $-\widehat{\widehat{c}}$ & $-\widehat{\overparen{\vec{n}}}$ & $\underset{n}{e}$ & $\infty 0$ \\
\hline & $\ddot{\vec{~}}$ & -6 & $\stackrel{e}{e}$ & $\stackrel{e}{e}$ & $-\frac{\tilde{n}}{\hat{\sigma}}$ & 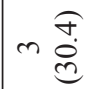 & - $\underset{\mathbb{J}}{\stackrel{f}{+}}$ & $-\stackrel{6}{\varrho}$ & $\underset{n}{e}$ & $\pm \widehat{\ominus}$ \\
\hline & $\stackrel{\Delta}{\sim}$ & $-\hat{\theta}$ & $\stackrel{e}{e}$ & $\stackrel{e}{e}$ & $-\underset{\hat{\sigma}}{\hat{d}}$ & $m \frac{6}{2}$ & $-\underset{\hat{\sigma}}{\hat{\theta}}$ & $-\widehat{\Xi}$ & $\underset{n}{e}$ & $\pm \widehat{\ominus}$ \\
\hline \multirow{5}{*}{ 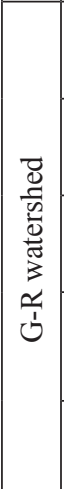 } & $\bar{\hbar}$ & $n \stackrel{\theta}{\theta}$ & 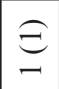 & $\stackrel{e}{e}$ & $-\underset{n}{\infty}$ & $m \frac{\widehat{F}}{c}$ & $m \frac{\widetilde{n}}{\mathrm{~d}}$ & $-\widehat{\overparen{\sigma}}$ & $\underset{n}{\hat{e}}$ & $\infty 0$ \\
\hline & F & $n \stackrel{6}{=}$ & $\stackrel{e}{e}$ & $\stackrel{e}{e}$ & $-\underset{\hat{\Phi}}{\stackrel{\infty}{\infty}}$ & $n \underset{\overbrace{}}{\stackrel{f}{\sigma}}$ & $-\stackrel{\widehat{\vec{m}}}{\vec{g}}$ & 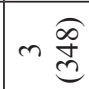 & $\underset{n}{e}$ & $\therefore 0$ \\
\hline & $\ddot{m}$ & $-\widehat{\varrho}$ & $\underset{c}{e}$ & $\Xi$ & $-\frac{\hat{\sigma}}{\dot{\sigma}}$ & 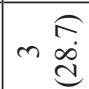 & $-\widehat{\hat{n}}$ & $-\sqrt{\tilde{b}}$ & $\underset{n}{e}$ & $\pm \widehat{\ominus}$ \\
\hline & $\ddot{\bar{z}}$ & $m \stackrel{\Omega}{=}$ & $\Xi$ & $\Xi$ & $-\frac{\widehat{m}}{\stackrel{\infty}{\infty}}$ & $-\frac{\pi}{\hat{\theta}}$ & $-\stackrel{\overparen{?}}{=}$ & $m \frac{\widehat{I}}{d}$ & $\underset{n}{\hat{e}}$ & $\because 0$ \\
\hline & $\vec{w}$ & $n \stackrel{6}{=}$ & $\Xi$ & $\Xi$ & $-\frac{\tilde{n}}{\infty}$ & $m \frac{\sqrt{n}}{\mathcal{E}}$ & $\ln \frac{\widehat{n}}{g}$ & $-\widehat{\sigma}$ & $\mathfrak{c}_{n}$ & $\therefore 0$ \\
\hline \multicolumn{2}{|c|}{ 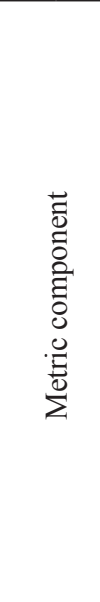 } & 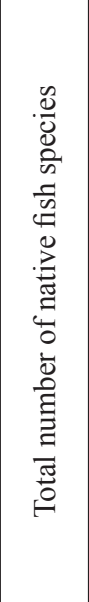 & 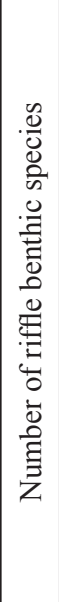 & 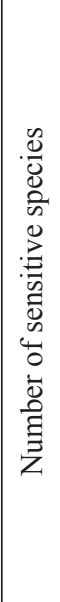 & 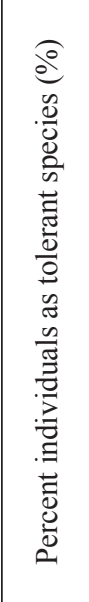 & 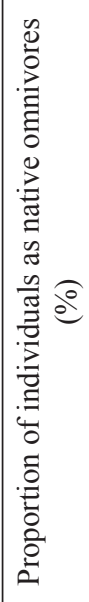 & 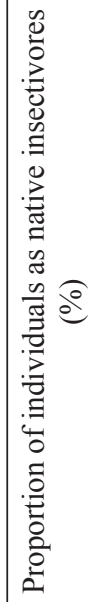 & 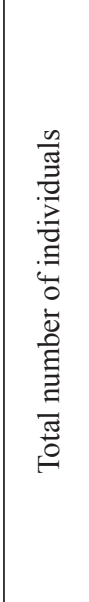 & 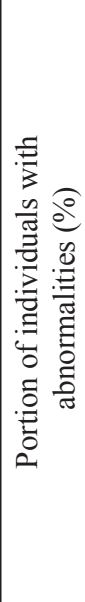 & \multirow[t]{3}{*}{ 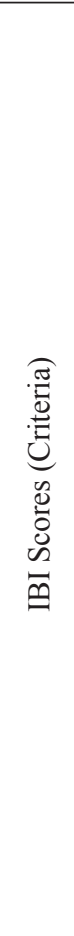 } \\
\hline 泀 & 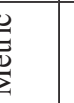 & $\bar{\Sigma}$ & $\tilde{\Sigma}$ & $\tilde{\Sigma}$ & $\sum^{ \pm}$ & $\sum^{n}$ & $\sum^{0}$ & $\Sigma$ & $\sum^{\infty}$ & \\
\hline & & \multicolumn{4}{|c|}{ 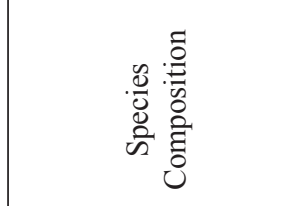 } & \multicolumn{2}{|c|}{ 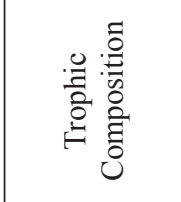 } & \multicolumn{2}{|c|}{ 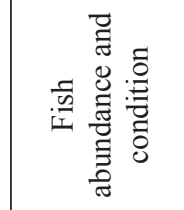 } & \\
\hline
\end{tabular}


for stream trophic states [50] upstream of weirs, this indicates a eutrophic state. In the G-R, this status decreased during the rainy season and increased after the end of the rainy season. In the Y-R watershed, TP continued to increase. In the N-R, the rainfall in July brought a large influx of nutrients from surrounding regions, resulting in a drastic increase in $\mathrm{TN}$ and $\mathrm{TP}$ concentrations, although these levels fell after the end of the rainy season. BOD averaged less than $4 \mathrm{mg} / \mathrm{L}$, with no significant differences among study periods. The N-R experienced a drastic increase in suspended solids from an average of $4 \mathrm{mg} / \mathrm{L}$ to $30 \mathrm{mg} / \mathrm{L}$, showing a similar
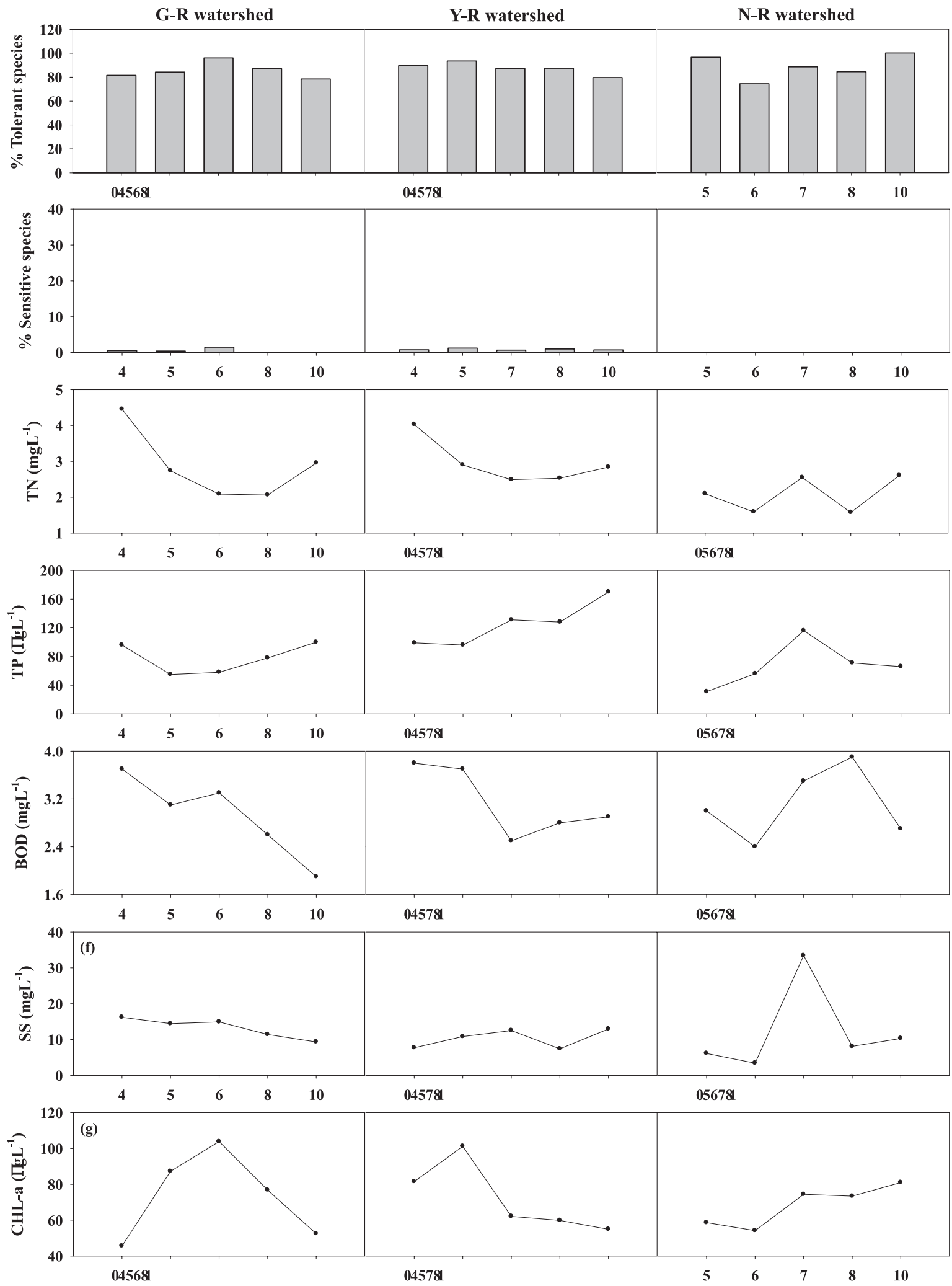

Fig. 6. Variation in fish tolerance guild and water quality metrics in 2016 (X-axes $=$ sampling month). 

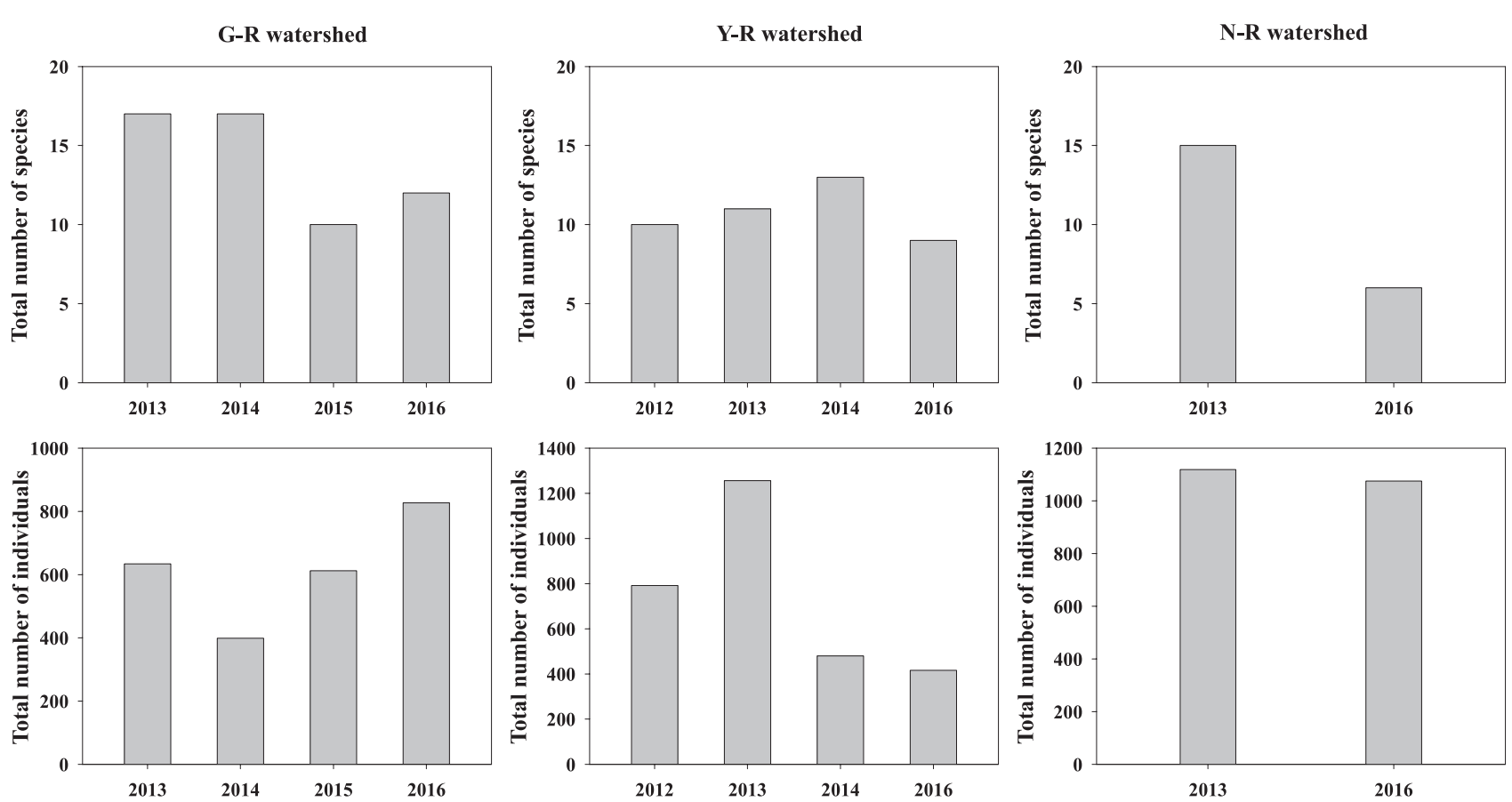

Fig. 7. Annual trends in the total number of species and total number of individuals in the fishways ( 2015 data for the Y-R watershed and 2014-2015 data for the N-R watershed were unavailable).

trend to that of TN and TP, which were indicators of eutrophic states. CHL-a ranged from 40 to $100 \mu \mathrm{g} / \mathrm{L}$, which indicates eutrophic conditions at all locations according to the stream nutritional status standards set by Dodds et al. [50]. Water quality appeared to have decreased with increased hydraulic water residence time and became stagnant, which then resulted in higher concentrations of pollutants.

For the fishway in the G-R watershed, we compared our results with those of the Environment Foundation Research Work on the G-R watershed from 20122015 [51] to assess changes in the numbers of species and individuals by year (Fig. 7). In 2013, following the construction of the weir, a total of 17 species and 634 individuals were collected, with E. erythropterus the dominant species and Hemiculter eigenmanni the subdominant species. In 2014, a total of 17 species and 399 individuals were collected, with $H$. labeo the dominant species and Opsariichthys uncirostris amurensis the subdominant species. In 2015, a total of 10 species and 612 individuals were collected; the dominant species was Microphysogobio jeoni and the subdominant species was E. erythropterus. In this study in 2016, a total of 12 species and 827 individuals were collected; the dominant species was $S$. japonicus coreanus and the subdominant species was H. labeo, which indicates distinct differences in abundance and composition in the fishways.

Many $M$. salmoides migrated using the fishway after the construction of the $\mathrm{J}_{\mathrm{s}}-\mathrm{w}$; however, the number of individuals decreased rapidly from the 2014 research period to this study in 2016. Overall, we found differences in dominant species by year; however, there were few species composition differences between the previous study and this one. However, the number of individuals using the fishway decreased in the 2016 study period compared to the other periods. Moreover, the decreasing trend continued over time. In the 2012 research period, Culter brevicauda, , a Level II Endangered species, migrated using the fishways, but they have not been found in the fishways since 2012 . We compared the results of this study for the fishway at the N-R watershed to evaluations of fish passage efficiency at $\mathrm{D}_{\mathrm{s}}-\mathrm{w}$ [52] conducted in 2013. After the construction of $\mathrm{D}_{\mathrm{s}}-\mathrm{w}$, the 2013 study collected a total of 15 species and 1,119 individuals; the dominant species was E. erythropterus, and the subdominant species was Squalidus chankaensis tsuchigae. A total of 6 species and 1,082 individuals were collected in the present study, and the dominant species were E. erythropterus and H. labeo. Thus, the dominant species were the same as those in the 2013 study, and they remained at high proportions.

\section{Fishway Efficiency Evaluations}

The multimetric fishway assessment model, based on the approach of Choi et al. [41], was used to evaluate the ice harbor fishways. The key metrics consisted of structural, hydrological, and biological characteristics: M1, slope of fishway; M2, ratio of fishway width to stream width; M3, orifice clogging proportion/size; M4, depth at fishway entrance; M5, depth at exit tail; M6, current velocity within fishway; M7, ratio of fish species within fishway to upstream/downstream of weir; M8, fish length distribution in fishway; and M9, proportion 


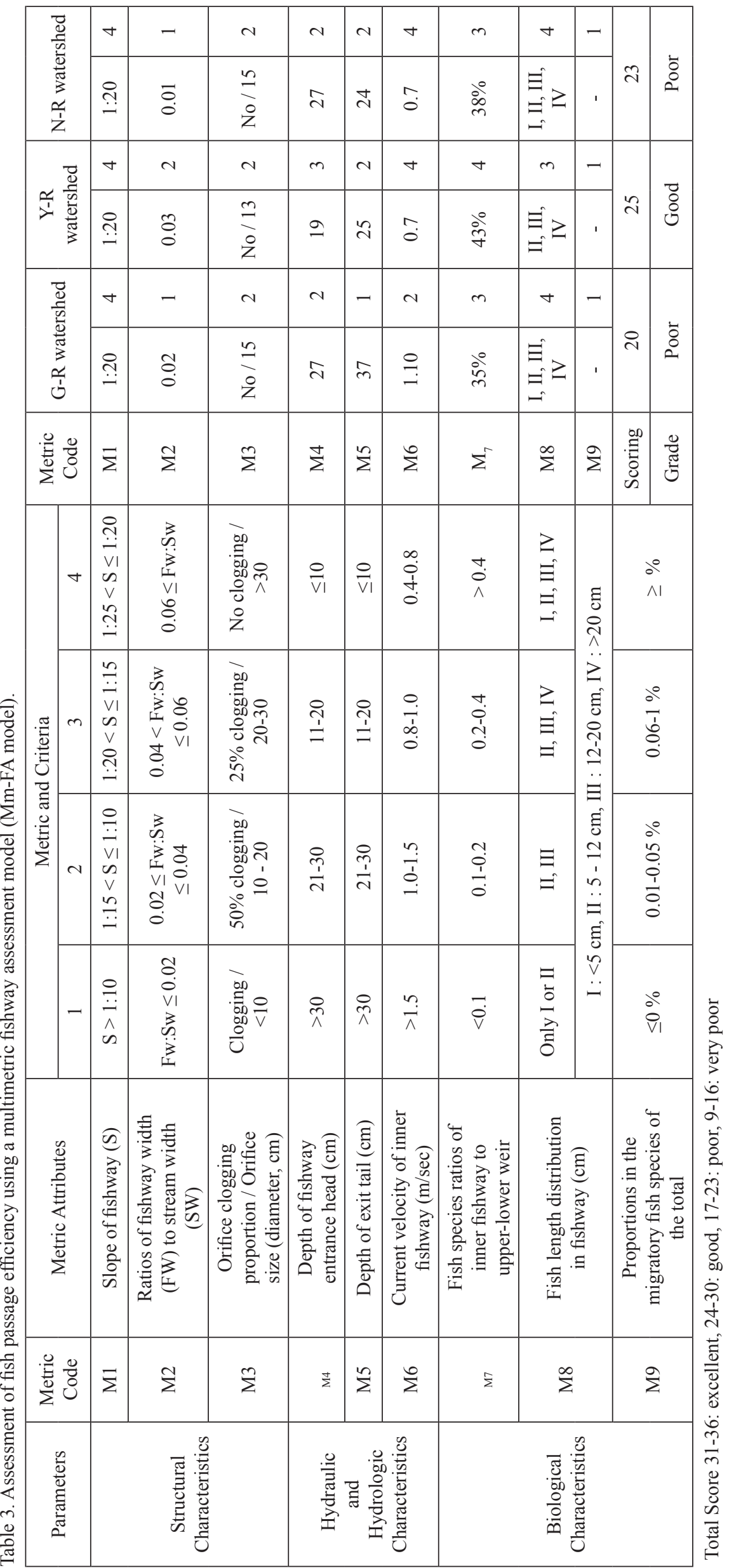


of migratory fish species. We used this multimetric fish assessment model to evaluate the efficiency of the three ice harbor fishways (Table 3). The fishway has a slope appropriate for the ascent of fish, and the spillway depths at its entrance head and exit tail are appropriate for swimming and jumping of fish. Moreover, as it was shown that species living in upstream and downstream reaches of the weir use the fishway, the fishway efficiency was high. In order to apply the Mm-FA model to weirs of various sizes, it was deemed necessary to adjust several metric properties and characteristics of indices. When applying the adjusted model to weirs in the four major rivers of Korea, the Mm-FA model will be a core model, suitable for evaluation of fishway efficiency.

\section{Structural Conditions of Fishways}

The structural metric of slope (M1) evaluated fish passage efficiency. Noonan et al. [53] showed that fish passage was most efficient when the slope was less than $3 \%$. Efficiency was lowest in fishways with slopes higher than $10 \%$. All ice harbor fishways in the watersheds had the same slope of 1:20, with the highest possible score of 4 . However, most ice harbor fishways in Korea have a gradient of 1:20, so this will need to be adapted for future applications of this model.

The M2 metric, the ratio of fishway width to stream width, was used to evaluate the movement of migratory fish species in the artificial weirs. The Korean Ministry of Environment (MEK) [54] suggested that the size and flow volume for fish passage must be considered when fishways are constructed. In this study, all fishways had a narrower width than rivers (0.01-0.03), which indicates a low score of 1 for the ratio of fishway width to stream width.

The M3 metric evaluated orifice clogging size and its effects on fish movement. The presence of sediments within a fishway clogs its orifices, restricting the movement of benthic fish species. In this study, the orifices were not clogged; however, we determined that their diameters were small and restricted the movement of benthic species, for a final metric score of 2 .

\section{Hydrological Conditions}

The hydrological metrics were the depth at the fishway entrance (M4) and the depth at the exit tail (M5). These metrics influence the flow velocity of fish passing through the fishway. The M6 metric evaluated swimming ability and jumping capability in the fishways. These hydrological metrics indicated that the depth of the fishway entrance of the G-R fishway $(37 \mathrm{~cm})$ led to a blockage caused by the weir, resulting in the lowest score of 1 for hydrological characteristics (M4). The flow velocity of the G-R fishway was the fastest among the three fishways at $1.10 \mathrm{~m} / \mathrm{s}$, with a score of 2 , lower than that of the Y-R and N-R fishways with scores of 4 and flow velocities of $0.7 \mathrm{~m} / \mathrm{s}$.
The fishway at the Y-R watershed weir had an entrance depth of $19 \mathrm{~cm}$, suitable for fish movement, and was given a score of 3 . The depth of the exit tail was $25 \mathrm{~cm}$ and was scored as 2 . The fishway at the N-R watershed weir had an entrance depth and exit tail depth of 27 and $24 \mathrm{~cm}$, respectively, and a score of 2 .

\section{Biological Conditions}

The M7 metric assessed the ratio of fish species within the fishway to upstream and downstream of the weir and evaluated the diversity and abundance of fish species passing through the fishways. Approximately $43 \%$ of the total fish species (9 out of 21) used the fishway in the Y-R watershed; the score was 4, which indicates higher usage of the Y-R fishways compared to the fishways at the other two watersheds.

To evaluate the relationship between fish species passing through the ice harbor fishway and current velocity, we assessed the number of species within the fishway and upstream and downstream of the weir versus the number of species passing through the fishway (Fig. 8). Fish passage was inversely related to current velocity in the fishways.

Increased current velocity decreased the number of species using the fishway, and some fish species were unable to migrate upstream.

MEK [54] emphasized that the ability of a fish to migrate through a fishway depends on species and total length. Most fish were able to migrate at a flow velocity of $0.5-1.0 \mathrm{~m} / \mathrm{s}$. In the three fishways, the current velocity was $0.9 \pm 0.22 \mathrm{~m} / \mathrm{s}$ during the study period, and it was $47.7 \pm 14.9 \%$. Regression analyses of fish passage efficiency showed a significant negative correlation $\left(R^{2}=0.463, P<0.05, n=11\right)$ with current velocity.

Overall, the model score for fish passage efficiency in the fishways was 20 (bad) in the G-R watershed, 25 (good) in the Y-R watershed, and 23 (bad) in the $\mathrm{N}-\mathrm{R}$ watershed. The Y-R fishway was suitable for fish passage, but the other two were not. The G-R and N-R

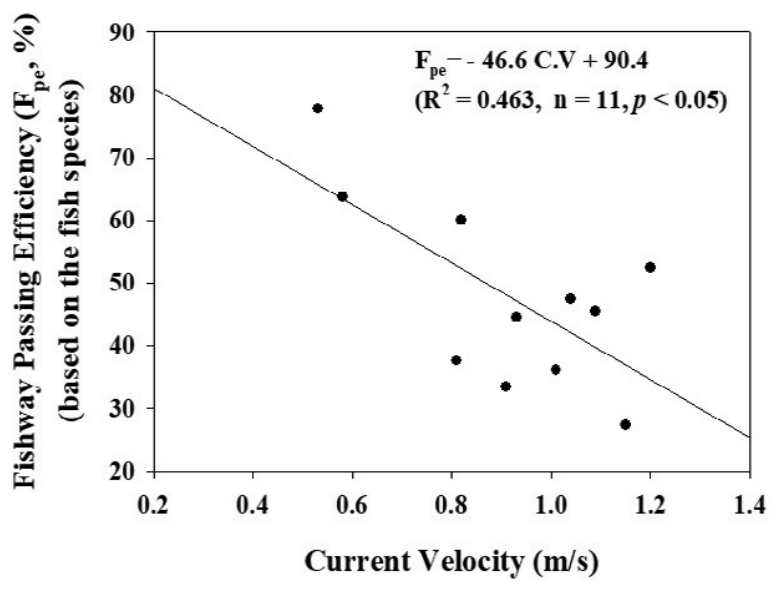

Fig. 8. Regression analysis of fish passage efficiency on the current velocity in the fishways. 
fishways should be restored to improve fish passage in those rivers.

\section{Acknowledgements}

This research was supported by the fund of Daejeon Green Environment Center under the Research Development Program (2017).

\section{Conflict of Interest}

The authors declare no conflict of interest.

\section{References}

1. JUN K.S., KIM J.S. The four major rivers restoration project: impacts on river flows. KSCE Journal of Civil Engineering, 15(2), 217, 2011.

2. LAH T.J., PARK Y., CHO Y.J. The four major rivers restoration project of South Korea: an assessment of its process, program, and political dimensions. The Journal of Environment \& Development, 24 (4), 375, 2015.

3. PARK Y., PYO J., KWON Y.S., CHA Y., LEE H., KANG T., CHO K.H. Evaluating physico-chemical influences on cyanobacterial blooms using hyperspectral images in inland water, Korea. Water Research, 126, 319, 2017.

4. BAEK K.O., KU Y.H., KIM Y.D. Attraction efficiency in natural-like fishways according to weir operation and bed change in Nakdong River, Korea. Ecological Engineering, 84, 569, 2015.

5. OLDEN J.D., NAIMAN R.J. Incorporating thermal regimes into environmental flows assessments: modifying dam operations to restore freshwater ecosystem integrity. Fresh water Biology, 55 (1), 86, 2010.

6. KO D.G., CHOI J.W., AN K.G. Preliminary Ecological Assessments of Water Chemistry, Trophic Compositions, and the Ecosystem Health on Massive Constructions of Three Weirs in Geum-River Watershed. Journal of Ecology and Environment, 39 (1), 61, 2016.

7. BAE M.J., MERCIAI R., BENEJAM L., SABATER S., GARCIA E. Small Weirs, Big Effects: Disruption of Water Temperature Regimes with Hydrological Alteration in a Mediterranean Stream. River Research and Applications, 32 (3), 309, 2016

8. NA E.H., PARK S.Y., KIM J.H., IM S.S., KIM K.H. A Study on Spatial and Temporal Patterns of Water Quality in the Middle Area of the Nakdong River, Korea. Journal of Korean Society on Water Environment, 31 (6), 723, 2015.

9. LEE E.H., KIM Y., KIM K., KIM S. Exclusive correlation analysis for algae and environmental factors in weirs of four major rivers in South Korea. Journal of Korea Water Resources Association, 49 (2), 155, 2016.

10. YOON B.B., LEE E.J., KANG T.A., SHIN Y.S. Longterm Change of Phytoplankton Biomass (chlorophyll-a), Environmental Factors and Freshwater Discharge in Youngsan Estuary. Korean Journal of Ecology and Environment, 46 (2), 205,. 2013.

11. KANG M.K., CHOI I.Y., PARK J.H., CHOI J.H. Investigation of the Effect of Weirs Construction in the Han River on the Characteristics of Sediments. Journal of
Korean Society of Environmental Engineers, 34 (9), 597, 2012.

12. YANG Y.M., SHIM M.J., OH D.Y., KHAN J.B., LEE J.B., HONG, S.H., LEE, S.H., PARK, S.J. Spatial Distribution of Heavy Metals in Geum River after Weirs Construction. Korean J Environ Agric., 34 (1), 64, 2015.

13. PELICICE F.M., POMPEU P.S., AGOSTINHO A.A. Large reservoirs as ecological barriers to downstream movements of Neotropical migratory fish. Fish and Fisheries, 16 (4), 697, 2015.

14. NOATCH M.R., SUSKI C.D. Non-physical barriers to deter fish movements. Environmental Reviews, 20 (1), 71, 2012.

15. KING S., O'HANLEY J.R. Optimal fish passage barrier removal-revisited. River Research and Applications, 32 (3), 418, 2016

16. CHOI J.W., PARK C.S., LIM B.J, PARK J.H, AN K.G. Fish passage evaluations in the fishway constructed on Seungchon weir. J. Env. Science International, 22 (2), 215, 2013.

17. KO D.G., CHOI J.W., LIM B.J., PARK J.H., AN K.G. Fish Distribution, Compositions and Community Structure Characteristics during Juksan-Weir Construction in Yeongsan River Watershed. Korean journal of environment and ecology, 26 (6), 892, 2012.

18. LEE J.H., HAN J.H., LIM B.J., PARK J.H., SHIN J.K. Comparative Analysis of Fish Fauna and Community Structures Before and After the Artificial Weir Construction in the Mainstreams and Tributaries of Yeongsan River Watershed. Korean Journal of Ecology and Environment, 46 (1), 103, 2013.

19. LANDSMAN S.J., MCLELLAN N., PLATTS J., VAN DEN HEUVEL M.R. Nonsalmonid versus Salmonid Passage at Nature- Like and Pool- and- Weir Fishways in Atlantic Canada, with Special Attention to Rainbow Smelt. Transactions of the American Fisheries Society, 147 (1), 94, 2018.

20. AHN S.S., LEE S.I., LEE Z.S. Analysis of hydraulic characteristics in ice-harbor fishway. Journal of Environmental Science International, 21, 1395, 2012.

21. HODGE B.W., FETHERMAN E.R., ROGERS K.B., HENDERSON R. Effectiveness of a Fishway for Restoring Passage of Colorado River Cutthroat Trout. North American Journal of Fisheries Management, 37 (6), 1332, 2017.

22. GARDA C., CASTLEDEN H., CONRAD C. Monitoring, Restoration, and Source Water Protection: Canadian Community-Based Environmental Organizations' Efforts towards Improving Aquatic Ecosystem Health. Water, 9 (3), 212, 2017.

23. WHITE L.J., HARRIS J.H., KELLER R.J. Movement of three non-salmonid fish species through a low-gradient verticalslot fishway. River Res. Appl., 27, 499, 2011.

24. BUNT C.M., CASTRO-SANTOS T., HARO A. Performance of fish passage structures at upstream barriers to migration, River Research and Applications, 28, 457, 2012

25. MEK(Ministry of Environment, Korea). Passage route survey of migratory before and after the construction of weirs and the fishway's effects, National Institute of Environmental Research(NIER), Incheon, Korea, 2011.

26. MELNYCHUK M.C., DUNTON K.J., JORDAAN A., MCKOWN K.A., FRISK M.G. Informing conservation strategies for the endangered Atlantic sturgeon using acoustic telemetry and multi-state mark-recapture models. Journal of Applied Ecology, 54 (3), 914, 2017. 
27. ROŻYŃSKI M., KAPUSTA A., DEMSKA-ZAKĘŚ K., HOPKO M., SIKORA A., ZAKĘŚ Z. The effects of surgically implanted dummy tags on the survival, growth performance, and physiology of pikeperch (Sander lucioperca). Fish Physiology and Biochemistry, 43 (4), 999, 2017.

28. SCHMIDT T., LØB C., SCHREIBER B., SCHULZ R. A Pitfall with PIT Tags: Reduced Detection Efficiency of Half-Duplex Passive Integrated Transponders in Groups of Marked Fish. North American Journal of Fisheries Management, 36 (4), 951, 2016.

29. HOSTETTER N.J., EVANS A.F., CRAMER B.M., COLLIS K., LYONS D.E., ROBY D.D. Quantifying Avian Predation on Fish Populations: Integrating PredatorSpecific Deposition Probabilities in Tag Recovery Studies. Transactions of the American Fisheries Society, 144 (2), 410, 2015.

30. KELLY B.B., CARY J.B., SMITH A.D., PREGLER K.C., KIM S., KANNO Y. Detection Efficiency of a Portable PIT Antenna for Two Small-Bodied Fishes in a Piedmont Stream. North American Journal of Fisheries Management, 37 (6), 1362, 2017.

31. JEPSEN N., THORSTAD E.B., HAVN T., LUCAS M.C. The use of external electronic tags on fish: an evaluation of tag retention and tagging effects. Animal Biotelemetry, 3 (1), 49, 2015.

32. HODGE B.W., HENDERSON R., ROGERS K.B., BATTIGE K.D. Efficacy of portable PIT detectors for tracking long-term movement of Colorado River cutthroat trout in a small montane stream. North American Journal of Fisheries Management, 35 (3), 605, 2015.

33. CHOI J.W, AN K.G. The Evaluations of Fish Survival Rate and Fish Movements using the Tagging Monitoring Approach of Passive Integrated Transponders (PIT), Journal of Environmental Science International, 23 (8), 1495, 2014.

34. NAU G.S., SPARES A.D., ANDREWS S.N., MALLORY M.L., MCLELLAN N.R., STOKESBURY M.J.W. Body size, experience, and sex do matter: Multiyear study shows improved passage rates for alewife (Alosa pseudoharengus) through small-scale Denil and pool- and- weir fishways. River Research and Applications, 33 (9), 1472, 2017.

35. LEE J.W., YOON J.D., KIM J.H., PARK S.H., BAEK S.H, YOON J.H., JANG M.H. Efficiency Analysis of the Ice Harbor Type Fishway Installed at the Gongju Weir on the Geum River using Traps. Korean J. Environmental Biology, 33 (1), 75, 2015.

36. BAEK K.O., KIM Y.D. A case study for optimal position of fishway at low-head obstructions in tributaries of Han River in Korea. Ecological engineering, 64, 222, 2014.

37. HESS J.E., CAUDILL C.C., KEEFER M.L., MCILRAITH B.J., MOSER M.L., NARUM S.R. Genes predict long distance migration and large body size in a migratory fish, Pacific lamprey. Evolutionary applications, 7 (10), 1192, 2014.

38. KIM S.J., YU K.K., YOON B.M., LIM Y.S. A Numerical Study on Hydraulic Characteristics in the Ice Harbor-type Fishway. KSCE J. Civil Engineering, 16 (2), 265, 2012.
39. HAN J.H., KO D.G., LIM B.J., PARK J.H., AN K.G. Summer patterns and diel variations of fish movements using fish trap sampling technique in the Juksan weir, Korean J. Environ. Impact Assessment, 21 (6), 879, 2012.

40. PARK C.S., AN K.G. Fish passage assessments in the fishway of Juksan weir constructed in the downstream area of Youngsan-river watershed. Journal of Environmental Science International, 23 (8), 1513, 2012.

41. CHOI J.W., PARK C.S, AN K.G. Development of Fishway Assessment Model based on the Fishway Structure, Hydrology and Biological Characteristics in Lotic Ecosystem. Journal of Ecology and Environment, 39 (1), 71, 2016.

42. MOE/NIER. The survey and evaluation of aquatic ecosystem health in Korea, The Ministry of Environment/ National Institute of Environmental Research, Incheon, Korea. 73, 2008.

43. STRAHLER A.N. Quantitative analysis of watershed geomorphology. Transactions of American Geophysical Union 8 (6), 913, 1957.

44. KIM I.S. PARK J.Y. Freshwater fishes of Korea. Kyo-hak Publishing Co., Ltd. 30, 2002.

45. BARBOUR M.T., GERRITSEN J., SNYDER B.D. STRIBLING J.B. Rapid bioassessment protocols for use in streams and wadeable rivers: periphyton, benthic macroinvertebrates and fish. $2^{\text {nd }}$ Ed. EPA 841-B-99-002, 1999.

46. KARR J.R. Assessment of biotic integrity using fish communities. Fisheries 6, 21, 1981.

47. AN K.G., JUNG S.H., CHOI S.S. An evaluation on health conditions of Pyong-Chang river using the index of biological integrity (IBI) and qualitative habitat evaluation index (QHEI). Korean J. Limnol. 34, 153, 2001.

48. OHIO EPA. Biological criteria for the protection of aquatic life. Vol.III, Standardized biological field sampling and laboratory method for assessing fish and macroinvertebrate communities, 1989.

49. US EPA. Fish field and laboratory methods for evaluating the biological integrity of surface waters. EPA 600-R-92111. Cincinnati, Ohio 45268, 1993.

50. DODDS W.K., JONES J.R., WELCH E.B. Suggested classification of stream trophic state: distributions of temperate stream types by chlorophyll, total nitrogen, and phosphorus. Water Research 32 (5), 1455, 1998.

51. MEK (Ministry of Environment, Korea). Evaluation and improvement of fishway efficiency. Sejong, 2015.

52. YOON J.D., KIM J.H., IN D.S., YU J.J., HEO M.S., CHANG K.H., JANG M.H. Evaluation of movement pattern of Erythroculter erythropterus inhabit in the midlower part of Nakdong River using acoustic telemetry. Korean J. Limnol 45 (4), 403, 2012.

53. NOONAN M.J., GRANT J.W.A., JACKSON C.D. A quantitative assessment of fish passage efficiency. Fish and Fisheries 13, 450, 2012.

54. MEK (Ministry of Environment, Korea). Efficiency Evaluations of Fish Passage and the Management Strategies, 1-30, 2014. 